\title{
DIAGRAMMATIKUS ÉRVELÉS - A KÉTKEDÉS VÉGE?
}

\section{DIAGRAMMATIC REASONING: THE END OF SCEPTICISM?}

\author{
Amirouche Moktefi \\ egyetemi tanár \\ Ragnar Nurkse Department of Innovation and Governance \\ Tallinna Tehnikaülikool (TTÜ)/Tallinn University of Technology, Tallinn, Estonia \\ amirouche.moktefi@ttu.ee
}

\begin{abstract}
ÖSSZEFOGLALÁS
Matematikai kötetekben, tankönyvekben gyakran találkozhatunk grafikonnal vagy ábrával. Az efféle diagramot korábban csupán pedagógiai vagy heurisztikai eszköznek tekintették, amely hasznos ugyan a megismerésben, de az igazolásban fölösleges, sőt megbízhatatlan. A matematikafilozófia újabb fejleményei mindenképp segítenek lebontani a diagrammatikus érveléssel szembeni elő́téletet a matematikában. Ehhez azonban a szembenálló nézeteket a matematikai bizonyítás koherens elméletében kellene összebékíteni. Két olyan gondolatot fejtünk ki, amelyek megnyithatják az egységhez vezető utat. Az első lényege, hogy kijelentjük: a diagrammatikus érvelés nem egyenlő a diagrammal történő érveléssel. A második elképzelés szerint a valós (diagrammatikus) bizonyítás olyan eljárás, amely megteremti az ideális (nem csak diagrammatikus) formális bizonyítás lehetőségét (ami nem egyenlő a megvalósulásával). Ha sikerül megerősíteni e hidakat, akkor összeköthetik a diagramról élő szkeptikus, formális és gyakorlati nézeteket, olyan hálót alkotva, amelynek részeként a különféle diagrammatikus bizonyítások és bizonyítási eljárások megtalálhatják helyüket a matematikában.
\end{abstract}

\section{ABSTRACT}

One regularly meets with various charts and figures in mathematical books and textbooks. However, such diagrams were viewed as mere pedagogical and heuristic devices that one might use with benefit in the context of discovery but that are redundant and unreliable in the context of justification. New developments in the philosophy of mathematics certainly help to fight the prejudice against diagrammatic reasoning in mathematics. However, there still is a need for an account that would incorporate these apparently opposed views within a coherent theory of proofs in mathematics. We will explore two ideas that might open the way to a reconciliation. The first simply consists in not equating diagrammatic reasoning and reasoning with a diagram. The second considers real (diagrammatic) proofs as practices that convey the possibility (rather than the actuality) of ideal formal proofs (whether diagrammatic or not). These bridges, if strengthened, would connect the sceptical, formal and practical views of diagrams and provide a net within which the variety of diagrammatic proofs and proving practices would find room in mathematics.

${ }^{1}$ Fordította: Szalai Éva 
Kulcsszavak: matematikai bizonyítás, formális és informális, diagrammatikus érvelés, levezetés, matematikafilozófia, rigorózus-formális diagrammatikus rendszer, egységes bizonyításelmélet

Keywords: mathematical proof, formal and informal, diagrammatic reasoning, derivation, philosophy of mathematics, rigorous formal diagrammatic system, a coherent theory of proofs

\section{BEVEZETÉS}

A diagramok matematikai alkalmazását régóta kétkedve fogadják. Mivel a matematikai bizonyítást formálisnak, a diagramot viszont informálisnak tartották, ábrának nem lehetett helye a bizonyításban. Matematikai kötetekben, tankönyvekben gyakran találkozhatunk grafikonnal vagy ábrával. Az efféle diagramot azonban csupán pedagógiai vagy heurisztikai eszköznek tekintették, amely hasznos ugyan a megismerésben, de az igazolásban fölösleges, sőt megbízhatatlan. Mégis jó ideje foglalkoztatja a matematika müvelöit, és mostanában egyre többször felvetödik a kérdés, hogy milyen szerepet tölthet be a tudományos gyakorlatban és a tanításban.

Nemrégiben magam is írtam két fő fejlődési irányról, amelyek bizonyíthatják, hogy itt nincs helye kétkedésnek (Moktefi, 2017). Egyrészt kiderült, hogy igenis kidolgozható meghatározott szabályokat követő, szigorú, formális diagrammatikus rendszer. Vagyis nem kell elvetnünk a formális bizonyítás ideálját, mert a „formális" magyarázat tartalmazhat ábrákat. Másrészt az is felvetődött, hogy a matematikus sem konstruál ideális bizonyítást napi munkája során, hanem inkább csak olyan gyakorlatias bizonyítással áll elö, amely a többi matematikus meggyőzéséhez elegendő. Vagyis a diagramot nem kell „formalizálni” ahhoz, hogy „elfogadható” bizonyítás része lehessen. Az efféle ,gyakorlati” bizonyításban az ábrákat inkább eszköznek tekintik, amellyel képzeletben dolgozhatunk a problémamegoldás meghatározott kontextusában.

Az utóbbi idők diagramokkal foglalkozó tanulmányaiban a formális és a gyakorlati magyarázatra is találhatunk példát (Chapman et al., 2018). Bár a kettő hívei abban egyetértenek, hogy szembe kell szállniuk a kétkedőkkel, bizonyos mértékig egymással is vitatkoznak: a formális nézetet azért bírálják, mert nem természetes, a gyakorlati nézetet pedig azért, mert gyanújuk szerint nem felel meg a matematikai „szigor” követelményének. Cikkemben ezeket az ellenvetéseket veszem sorra. Kifejtem, hogy az első kifogás alapja az az indokolatlan feltevés, hogy a diagrammatikus érvelés szükségképpen (egy-egy) diagrammal történő érvelés. A második kifogásra episztemológiai stratégiákkal, például a sokat vitatott „levezetésmutató” elvvel adhatunk méltó választ. 


\section{SZABAD KÉPZELET ÉS SZABÁLYOK}

A diagramokkal végzett műveletek során (például jelölés hozzáadásakor, elforgatásakor, vagy amikor egyszerủen „nézőpontot váltunk”) gyakran úgy beszélünk cselekvésünk eredményéről, mintha ugyanaz a diagram lenne, némiképp „transzformált" változatban, és nem egy teljesen új ábra, amelyet az eredetiből „levezettünk”. Ez mindjárt más értelmet nyer, ha sorozatot alkotó algebrai bizonyításról van szó, hiszen az új képletet a korábbiakból vezetjük le (és új sorba írjuk): „Némely képi bizonyítás, az Euler- és Venn-diagramok, valamint az euklidészi diagrammatikus demonstrációk konfiguráción belülinek tekinthetők annyiban, hogy az érvelés »az ábrán belül marad «. Többféleképpen is - néha rendezett lépések során át - megvizsgáljuk a diagramot, hogy megértsük, mit ábrázol. Az aritmetikai és algebrai jelölések rendszerében (és a csomóelméletben) az érvelés inkább konfigurációk közötti, mert lépései megkövetelik, hogy új sorokat írjunk." (Macbeth, 2012, 64.)

Épp ezért első látásra természetellenesnek tünik, hogy a diagramot tárgyként fogjuk fel, amelyen a szabályoknak megfelelően levezetési müveleteket végezhetünk. Vagyis mondhatnánk, hogy a „formalisták” a diagramokat olyan keretek közé szorítják, ahol „természetesen” nem lenne helyük (Giardino, 2013). Mégis könnyen eszünkbe juthatnak olyan esetek, amikor a képek sorozatot, szekvenciát alkotnak. Nyíri Kristóf a „mozgó képeket” taglalva megjegyzi: ,egy-egy statikus kép érzékletesen felidézhet valamilyen jelenetet vagy helyesen ábrázolhat valamilyen látványt, de nyilvánvalóan nem tudja kifejezni a tényállást; önmagában nem hordozhat állítást. [...] Természetesen az egyes kép egyértelmüvé válhat, ha felirattal egészítjük ki. De jelentését úgy is tisztázhatjuk, hogy beillesztjük egy képsorozatba - amit az egyedülálló kép nem fejezhet ki, azt a sorozat, a képek egymásutánja igen: elmesélheti a történetet.” (Nyíri, 2017, 109.)

Nyíri példaként említi a képregényt - amely időben egymást követő, beszédbuborékokat tartalmazó képek sorozataként jelenik meg -, és emlékeztet, hogy ennek konvencióit még a legkisebb gyerek is könnyen megérti. Gondolhatunk olyan esetekre is, amikor a kép mozgatása, manipulációja egy sor újabb, előhívható vagy a szemlélő elméjében maradó részképet hoz létre. Például a turistatérképet gyakran összehajtjuk, hogy a minket érdeklő helyre összpontosítsunk, így résztérkép keletkezik. Hasonlóképpen kereshetünk egy bizonyos közlekedési útvonalat: figyelmen kívül hagyunk minden olyan térképszelvényt, amely épp nem kell. Ekképpen úgy alkothatunk mentális képet egy résztérképről, hogy közben nem is hajtogatjuk a térképet.

Hasonló diagramszekvenciákat találunk a matematikában. A Bizonyitás szavak nélkül könyvsorozat sok példája épp ilyen szekvenciákból áll (Nelsen, 19932015). Silvia De Toffoli és Valeria Giardino jó példát adnak erre a csomóelméletről szóló müvükben. A csomók átrendezése tulajdonképpen úgy történik, hogy 
ábrájukat egy lépéssorozaton keresztül új diagrammá alakítják. Vagyis az eredményes manipuláció megkövetel „egyfajta manipulatív képzeletet, amely gyakorlással fejlödik: azáltal, hogy manipulatív képességeinket átvisszük a konkrét tárgyról annak jelölésére”. Ekkor „a diagram a »kísérletezés« eszköze és tárgya lesz, amellyel az ebben jártas kísérletező az érvelés következtetési lépéseinek megfelelö episztemikus tevékenységeket végezhet" (De Toffoli-Giardino, 2014, 839-840.). Tehát egyáltalán nem ritka, hogy a diagram szabályokat követő átrendezésével hoznak létre szekvenciát. A diagram manipulálása során persze a felhasználónak nem kell explicit módon megfogalmazni a szabályokat. Mégis igaz, hogy a konkrét kontextushoz illő diagram „nem csupán az oldalt díszítő képek sora, hanem magában foglalja használatának szabályait” (Legg, 2013, 14.).

Sőt mi több, már az is vitatható, hogy az „egyedülálló” diagram természetes. Például az Euler-diagramot általában erős ikonikus jellege és természetessége miatt dicsérik (Moktefi, 2015). Ha azonban megnézzük történeti elözményeit és szemiotikai tulajdonságait, akkor látható, hogy meghatározott problémák megoldására szerkesztették, ezért más esetekben nem válik be. ${ }^{2}$ Vagyis nem feledkezhetünk meg arról, hogy a diagram kialakítása mindig a betöltendő funkciója szerint történik. A képzelőerő matematikai szerepéről mostanában folytatott viták is azt sugallják, hogy a diagramot ilyen konstrukcióként kellene felfognunk.

E viták során felvetődött: a képzelet kötött annyiban, hogy nem tud magyarázatot adni a matematikai lehetetlenségre. Például úgy tartják, hogy nem lehet elképzelni kör alakú négyzetet, hiszen bármi is ötlik a képzeletünkbe, az nem lehet egyszerre kerek és szögletes (Béziau, 2016). Nem világos azonban, miért függene a képzelőerő attól, hogy helyes-e az elképzelt tárgy. Ellenkezőleg: épp az a képzelet érdeme, hogy új - akár kerek, akár szögletes - objektumokat hoz létre, amelyek akkor jutnak eszünkbe, ha „kör alakú négyzetet” kell elképzelnünk. Hugh MacColl találó észrevétele: „Láttunk és rajzoltunk már háromszöget; de ma még értelmetlennek tartjuk a »kör alakú négyzetet«. A jövőben fejlődhet úgy az angol nyelv, hogy utódaink egy nap majd jelölhetik a valóság egy darabját ezzel a kifejezéssel, akkor pedig nem lesz többé valószerütlen - éppen úgy, ahogy ma a horseman nem ló és ember valószerütlen elegyét jelöli, nem lóembert vagy kentaurt, hanem valódi lovon ülő valódi embert: lovast jelent." (MacColl, 1907)

Ráadásul azt is állítjuk, hogy igenis elképzelhető (vizualizálható) olyan objektum, amely valóban egyszerre kerek és szögletes. Ehhez magának a képnek nem kell kereknek vagy szögletesnek lennie. Elegendő, ha a képzeletben megjelenő „kör alakú négyzet” ugyanúgy viszonyul a kerekséghez és a szögletességhez,

${ }^{2} \mathrm{Az}$ Euler-diagram kevésbé használható például intenzionális értelmezésekben (lásd Stapleton et al., 2018). 
mint maga a tárgy. Például egyszerüen rajzolhatunk olyan Euler- (vagy Venn-) diagramot, amelyet két egymást átfedő terület alkot. Az egyik terület a kerekséget jelölheti: ide kerül minden kerek objektum. A másik terület a szögletességet jelölheti: ide lehet gyüjteni az összes szögletes tárgyat. Következésképpen a kettő metszete olyan tárgyakat tartalmaz majd, amelyek mindegyike egyszerre lehet kerek és szögletes. Elegendő egy jelet, például egy pontot tenni a metszet területére, és az máris egy minden követelménynek megfelelő „kör alakú négyzetet” jelöl. ${ }^{3}$ Persze lehet, hogy ez a diagram nem az a „mentális kép”, amelyre egy-egy olvasó számított, de ez csak abból fakad, hogy szükségtelen követelményeket támasztottak e „lelki képpel” szemben. Például egy szervezet „organigramjában” a csomópontoknak (vagy kereteknek) nem kell fizikailag hasonlítaniuk az emberre, akit képviselnek. Mindössze annyi szükséges, hogy összekapcsolódásuk módja megmutassa a szervezeti struktúra belső viszonyait. ${ }^{4}$

\section{BIZONYÍTÁSOK ÉS LEVEZETÉSEK}

Az utóbbi idők szakirodalmában többen is dicsérték a többértelműség szerepét a matematikai felfedezésben (Grosholz, 2007; Byers, 2007). A csomóelméletben például a gráfok határozatlansága számos lépést tesz lehetővé, így megmozgatja a manipulatív képzeletet, amely a képzéssel és a tudásgyarapodással fejlődik (De Toffoli-Giardino, 2014, 839.). Ezt a produktív többértelmüséget azonban bírálatok is érték, mert „sokszor vezette tévútra a matematikusokat, hogy intuitív módon hihető, de végső soron félrevezető gondolatmenetet alkalmaztak, amely a többértelmüséget, a homályosságot vagy más problematikus jellemzőt próbál kihasználni”. Eszerint ,,az igazolás kontextusában a megfelelöen kidolgozott elméletnek teljesítenie kell a szigorúság követelményeit, amelyek sokkal kötöttebbek, mint a felfedezés kontextusában érvényes követelmények" (Jesseph, 2008).

Nemrégiben egy tanulmányban jómagam is említést tettem az episztemológiai stratégiákról, amelyekkel a tudósok igyekeznek visszaszorítani a kísérleti tevékenységüket eredendően jellemző bizonytalanságokat (Moktefi, 2017). Allan Franklin egy sor ilyen stratégiát ismertetett, és megállapította, hogy azok „meglehetősen meggyőzőek a kísérleti eredmények érvényességét illetően. Ezek a stratégiák különbséget tesznek az érvényes megfigyelés vagy mérés és a kísér-

\footnotetext{
${ }^{3} \mathrm{Az}$ Euler-diagramon a pont magát az egyes elemet (a kör alakú négyzetet) képviseli, a Venndiagram viszont inkább csak azt jelzi, hogy ez az elem létezik. Az utóbbi idők diagrammatikus rendszerei, például a pókháló-diagramok kifejezőbbek az egyes elemek reprezentációja szempontjából (lásd Moktefi-Pietarinen, 2015).

${ }^{4}$ A kapcsolatok diagrammatikus megjelenítéséről és ennek szerepéről a diagramok felhasználhatóságában lásd Carter, 2017.
} 
leti apparátus által létrehozott tárgy között" (Franklin, 1990, 103-104.). Említett cikkemben kifejtettem, hogy e stratégiák a matematikusok körében is megtalálhatók, főként ha diagramok manipulálásáról van szó. Például a diagram „kalibrálható", hogy ellenőrizzék a megbízhatóságát, és kizárják a nemkívánatos jellemzőket. Ezenkívül ott is megtalálható az inter-instrumentalitás stratégiája (többféle eszközzel is ellenőrzik, hogy helytálló-e a kísérleti eredmény), ahol a matematikus különbözö úton-módon (diagrammal, algebrai notációval, számítógéppel stb.) újra kiszámítja az eredményt, hogy ezzel is bizonyítsa a tételt. E gyakorlati álláspont szerint a diagram úgy erősíti a matematikai bizonyítás érvényességét, hogy nem szükséges formális diagrammatikus rendszert létrehozni.

Talán az efféle stratégiák nem győzik meg azt az olvasót, aki a bizonyítást leginkább olyan lineáris levezetésnek tartja, amely „véges számú képletből álló szekvencia, és benne minden terminus vagy axióma, vagy az adott szekvencia korábbi terminusainak egy halmazából valamelyik következtetési szabály alkalmazásával kapott eredmény” (Pelc, 2009, 85.). ${ }^{5} \mathrm{E}$ „formalista” olvasót csak úgy győzhetjük meg az informális bizonyítás helyes voltáról, ha jelezzük az alapjául szolgáló levezetést. A matematikai bizonyítások efféle „levezetésmutató nézetét” Jody Azzouni szorgalmazta: „A köznapi matematikai bizonyítások jelzik, milyen (egyik vagy másik) mechanikusan ellenőrizhető levezetéssel juthatunk a kiindulásként választott feltevésektől a tételekhez. A mutató-nézet magyarázatot ad arra, miért bólintanak a matematikusok oly készségesen a köznyelven megfogalmazott bizonyítások eredményeire, amelyeket (nyilvánvalóan) nem lehet mechanikusan ellenőrizni." (Azzouni, 2004, 105.)

Ezt a nézetet már tüzetesen taglalták, és több okból is bírálták a mai matematikafilozófiában (Larvor, 2016). Jelesül azért kifogásolták, mert „nemcsak arról van szó, hogy a matematikai bizonyítások tartalmaznak olyan összetevőket, amelyeket formális számításokkal nem lehet megragadni, hanem tulajdonképpen arról is, hogy sok tétel esetében nem találunk összefüggést a bizonyítás és az alapjául szolgáló hipotetikus levezetés között" (Pelc, 2009, 85.).

Ha a „levezetésmutató nézetet” nem fogadjuk is el a matematikai bizonyítások magyarázatának általános elveként, episztemológiai stratégiaként még alkalmazható. Merthogy sok bizonyításban igenis lehet jelezni az alapul szolgáló levezetést. Ez kiváltképp az egyszerü bizonyítások, illetve olyan bizonyítások esetében képzelhető el, amelyek más, hézagos bizonyítások vázlataként vagy rövidített változataként alkalmazhatók. Érvelhetnénk azzal - ahogyan Lewis Carroll híres „teknőse” tette -, hogy a hézagot, távolságot csak végtelen sok lépéssel tudjuk áthidalni (Moktefi-Abeles, 2016). De ne feledjük: nem kell ténylegesen megmutatnunk a levezetéseket ahhoz, hogy erősödjön a bizonyításba vetett bizodalmunk.

\footnotetext{
${ }^{5}$ A matematikafilozófiai irodalomban a bizonyítás (proof) néha informális bizonyítást, a levezetés (derivation) pedig formális bizonyítást jelent (lásd Tanswell, 2015).
} 
Mindössze annyi kell az olvasó meggyőzéséhez, hogy az efféle levezetés szükség esetén bemutatható. Tehát még akkor sem kell megszüntetnünk az összes hézagot, ha a matematikai rések kitöltésére törekszünk. Inkább csak addig kell töltögetnünk a hézagokat, amíg új bizonyításunk elfogadásra nem talál. Ekkor a bizonyítás még mindig tartalmazhat hézagokat, de ezeket az olvasó már szükségképpen elfogadhatónak tekinti (Andersen, 2018).

Természetesen a levezetések a következtetési szabályok meghatározásában és alkalmazásában is megkövetelik a képzelőerőt. Vagyis bizonyos mértékig ugyanolyan ellenvetéseket válthatnak ki, mint a manipulatív képzelet. Nemcsak maguk a szabályok lehetnek hibásak, hanem végrehajtásukba is csúszhatnak hibás lépések. A hiba kockázata akkor sem zárható ki teljesen, ha a levezetés minden mozzanata megfigyelhető és mechanikusan ellenőrizhető. A stratégia célja mégis csupán annyi, hogy meggyőzze a kétkedő olvasót: a bizonyítás ,jelezheti” a levezetést, ebből pedig az következik, hogy az informális bizonyítás nem feltétlenül kevésbé megbízható, mint a jelzett levezetés. Az efféle levezetések hossza az ágenstől függ. Ha a bizonyítás 1. nem éri el az elfogadható levezetési szintet, vagy 2. elfogadásra talál, de hossza gátolja „a bizalom elnyerését”, akkor a „levezetésmutató” stratégiát eredménytelennek nyilváníthatjuk, és érdemes más episztemológiai stratégiával próbálkoznunk. A „levezetésmutató” stratégia mégis sokszor beválik.

Ez a stratégia persze diagrammatikus és nem diagrammatikus bizonyításokra egyaránt alkalmazható. Ha arról akarunk meggyőzni valakit, hogy helyes egy diagrammatikus bizonyítás, akkor egyszerüen jelezhetjük az alapjául szolgáló levezetést (akár diagrammatikus, akár nem). Azzouni már észrevételezte, hogy a diagrammatikus bizonyítást nem kell ,átvinni” egy nyelvre épülő rendszerbe, amennyiben mechanikus ellenőrizhetőséget jelez (Azzouni, 2013). Ha például képtelenek vagyunk „belátni” egy adott szillogizmus konklúzióját egy három terminust ábrázoló Venn-diagramon, akkor csak meg kell adnunk neki azokat a következtetési szabályokat, amelyek alapján ,kivonhatja” a konklúziót ebből a diagramból egy „derivatív”, az izolált konklúziót mutató kétterminusos diagramba. Ilyen eljárásra épül például Carroll Logikai játéka (Game of Logic): minden szillogizmus megoldható a két diagramból a táblán, amelyen korongok képviselik az állításokat (Moktefi, 2013).

\section{KÖVETKEZTETÉS}

Az újabb keletủ diagramvizsgálatok fejleményei megingatnak néhány elterjedt és nehezen szűnő félreértést. Egyre nagyobb az érdeklődés a diagram mint a matematikai felfedezés, bizonyítás és megértés eszköze iránt. Az e téren jelenleg folyó munka rámutat, hogy sokféle diagrammatikus bizonyítási eljárást 
alkalmazhatunk. Reményeink és várakozásaink szerint a jövőbeli kutatás még inkább megvilágítja majd azokat a bonyolult kérdéseket, amelyekkel ma szembe kell néznie mindenkinek, aki a diagrammatikus érvelés episztemológiája felé vezető úton jár. ${ }^{6}$

\section{IRODALOM}

Andersen, L. E. (2018): Acceptable Gaps in Mathematical Proofs. Synthese. DOI: 10.1007/s11229$018-1778-8$

Azzouni, J. (2004): The Derivation-Indicator View of Mathematical Practice. Philosophia Mathematica, 12, 81-105.

Azzouni, J. (2013): The Relationship of Derivations in Artificial Languages to Ordinary Rigorous Mathematical Proof. Philosophia Mathematica, 21, 247-254.

Béziau, J.-Y. (2016): Possibility, Imagination and Conception. Princípios, 23, 40, 59-95. https:// dialnet.unirioja.es/descarga/articulo/5890711.pdf

Byers, W. (2007): How Mathematicians Think: Using Ambiguity, Contradiction, and Paradox to Create Mathematics. Princeton: Princeton University Press

Carter, J. (2017): Exploring the Fruitfulness of Diagrams in Mathematics. Synthese, DOI: 10.1007/ s11229-017-1635-1

Chapman, P. et al. (eds.) (2018): Diagrammatic Representation and Inference. Berlin: Springer

De Toffoli, S. - Giardino, V. (2014): Forms and Roles of Diagrams in Knot Theory. Erkenntnis, $79,829-842$.

Franklin, A. (1990): Experiment, Right or Wrong. Cambridge: Cambridge University Press

Giardino, V. (2013): A Practice-Based Approach to Diagrams. In: Moktefi, A. - Shin, S.-J. (eds.): Visual Reasoning with Diagrams. Basel: Birkhäuser, 135-151.

Grosholz, E. R. (2007): Representation and Productive Ambiguity in Mathematics and the Sciences. Oxford: Oxford University Press

Jesseph, D. (2008): Review of Emily R. Grosholz's Representation and Productive Ambiguity in Mathematics and the Sciences. Notre Dame Philosophical Reviews, 05.15. https://ndpr.nd.edu/ news/representation-and-productive-ambiguity-in-mathematics-and-the-sciences/

Larvor, B. (2016): Why the Naïve Derivation Recipe Model Cannot Explain How Mathematicians' Proofs Secure Mathematical Knowledge. Philosophia Mathematica, 24, 401-404.

Legg, C. (2013): What Is a Logical Diagram? In: Moktefi, A. - Shin, S.-J. (eds.): Visual Reasoning with Diagrams. Basel: Birkhäuser, 1-18.

Macbeth, D. (2012): Seeing How it Goes: Paper-and-Pencil Reasoning in Mathematical Practice. Philosophia Mathematica, 20, 58-85.

MacColl, H. (1907): Symbolic Logic (A Reply). Mind, 16, 470-473.

Moktefi, A. (2013): Beyond Syllogisms: Carroll's (Marked) Quadriliteral Diagram. In: Moktefi, A. - Shin, S.-J. (eds.): Visual Reasoning with Diagrams. Basel: Birkhäuser, 55-71.

Moktefi, A. (2015): Is Euler's Circle a Symbol or an Icon? Sign Systems Studies, 43, 597-615.

${ }^{6}$ A kutatómunkát az Észt Kutatási Tanács (ECR) támogatja az „Abdukció a bizonytalanság korában" projekt keretében (PUT 1305, Abduction in the Age of Uncertainty, kutatásvezető: Prof. Ahti-Veikko Pietarinen). 
Moktefi, A. (2017): Diagrams as Scientific Instruments. In: Benedek A. - Veszelszki Á. (eds.): Virtual Reality - Real Visuality: Virtual, Visual, Veridical (Visual Learning, 7). Frankfurt: Peter Lang, 81-89.

Moktefi, A. - Abeles, F. (2016): The Making of "What the Tortoise Said to Achilles": Lewis Carroll's Logical Investigations toward a Workable Theory of Hypotheticals. The Carrollian, 28, $14-47$.

Moktefi, A. - Pietarinen, A.-V. (2015): On the Diagrammatic Representation of Existential Statements with Venn diagrams. Journal of Logic, Language and Information, 24, 361-374.

Nelsen, R. B. (1993-2015): Proofs without Words. Vols. 1-3. Washington, DC: Mathematical Association of America

Nyíri K. (2017): Pictorial Truth: Essays on Wittgenstein, Realism, and Conservatism. Dunabogdány: digitális szerzői kiadás. https://www.academia.edu/34190040/Pictorial_Truth_Essays_ on_Wittgenstein_Realism_and_Conservatism

Pelc, A. (2009): Why Do We Believe Theorems? Philosophia Mathematica, 17, 84-94.

Stapleton, G. et al. (2018): Euler Diagrams through the Looking Glass: From Extent to Intent. In: Chapman, P. et al. (eds.): Diagrammatic Representation and Inference. Berlin: Springer, 365-381.

Tanswell, F. (2015): A Problem with the Dependence of Informal Proofs on Formal Proofs. Principia Mathematica, 23, 295-310. 